\title{
Concentration of steroids in bovine peripheral plasma during the oestrous cycle and the effect of betamethasone treatment
}

\author{
L. N. Kanchev*, Hilary Dobson, W. R. Ward and R. J. Fitzpatrick \\ Department of Veterinary Clinical Studies, University of Liverpool, \\ Neston, Merseyside L64 7TE, U.K.
}

\begin{abstract}
Summary. Testosterone, oestradiol and progesterone were measured in peripheral plasma during the oestrous cycle of 6 heifers. Oestradiol and progesterone results confirmed earlier reports. Concentration of testosterone on the day of oestrus was $40 \pm 3 \mathrm{pg} / \mathrm{ml}$ (mean \pm S.E.M.), and two peaks were detected during the cycle, one 7 days before oestrus $(1809 \pm 603 \mathrm{pg} / \mathrm{ml})$ and the other $(78 \pm 7 \mathrm{pg} / \mathrm{ml})$ on the day before the onset of oestrus. The concentration of progesterone declined in most cases 1 day after the maximum concentration of testosterone.

Betamethasone treatment in 5 heifers extended luteal function by an average of 10 days: plasma androstenedione and oestradiol concentrations were unaltered; cortisol values were depressed for at least 16 days after treatment; testosterone concentrations were lowered by $13 \pm 2.4 \%$ during treatment, and except in one heifer the peak on Day -7 was abolished.
\end{abstract}

\section{Introduction}

Many steroids have now been identified in bovine peripheral plasma and much information has accumulated about their concentration and pattern of secretion during the oestrous cycle (Donaldson, Bassett \& Thorburn, 1970; Glencross, Munro, Senior \& Pope, 1973; Tribble et al., 1973; Dobson \& Dean, 1974). However, only Shemesh \& Hansel (1974) have considered testosterone concentrations in plasma during the bovine oestrous cycle, although it is well known that the ovaries secrete testosterone (Short, 1962; McCracken, Baird \& Goding, 1971; Judd \& Yen, 1973; Abraham, 1974). In the present study, the changes in plasma testosterone during the bovine oestrous cycle are compared with those of progesterone and oestradiol. To establish the origin of the plasma testosterone, adrenal function was suppressed by betamethasone treatment and the concentrations of progesterone, oestradiol, testosterone, cortisol and androstenedione were assessed.

\section{Materials and Methods}

\section{Animals}

Six non-pregnant Friesian heifers, with regular oestrous cycles, were bled daily ( 16.00 hours) for 30 days, by jugular venepuncture. Blood was collected into heparinized evacuated bottles and centrifuged immediately after collection. The plasma was removed and stored at $-18^{\circ} \mathrm{C}$ until assayed. Adrenal function was subsequently suppressed in 5 of the heifers by i.m. administration of $30 \mathrm{mg}$ betamethasone (Betsolan: Glaxo)/day from Day 10 (oestrus = Day 0 ) for 7 days and $20 \mathrm{mg}$ and $10 \mathrm{mg}$ on the 8 th and 9 th days of treatment respectively. The heifers were simultaneously treated i.m. with $750 \mathrm{mg}$ oxytetracycline (Terramycin Q: Pfizer). The heifers were observed for signs of oestrus, including ovarian palpation per rectum, and bled daily from the beginning of betamethasone treatment for 26 days.

\footnotetext{
* Present address: Institute of Biology and Pathology of Reproduction, Sofia-13, Bulgaria.
} 


\section{Testosterone assay}

Materials. General reagents were of Analar grade obtained from B.D.H. Chemicals Ltd. Diethyl ether was re-distilled immediately before use. Antiserum (B3R3RT) raised against testosterone-3carboxymethyloxime-BSA (Rowe $e t$ al., 1974) was donated by Dr P. H. Rowe. Antiserum and $\left[1,2,6,7-{ }^{3} \mathrm{H}\right]$ testosterone (sp. act. $100 \mathrm{Ci} / \mathrm{mmol}$ : Radiochemical Centre, Amersham) were each diluted in phosphate-buffered saline with gelatine (PBS-g) which consisted of $0 \cdot 1 \mathrm{M}$-phosphate buffer (pH 7.0) containing $0.9 \%$ sodium chloride, $0.1 \%$ gelatine and $0.01 \%$ thiomersal. Charcoal (Sigma, U.S.A.) (250 mg) was suspended in $100 \mathrm{ml}$ PBS-g. Scintillation fluid composed of three parts toluene (1 litre containing 3.0 g 2,5-diphenylotazole (PPO)) and one part Triton-X-114 (Koch Light Ltd) was used. Radioactivity was assessed using a Packard liquid scintillation spectrophotometer Model 3375.

Procedure. An appropriate volume of plasma ( $1 \mathrm{ml}$ in most cases) was transferred to stoppered test-tubes (B14: Quickfit). Duplicate plasma samples, recovery standards and blanks containing an equivalent volume of water were extracted with $2 \mathrm{ml}$ diethylether. After freezing the aqueous phase, the ether was decanted to smaller tubes and evaporated. Previously mixed antiserum $(0 \cdot 1 \mathrm{ml}$ at $1: 5000$ dilution) and radioactive testosterone $(0 \cdot 1 \mathrm{ml}$ containing $16,000 \mathrm{~d} / \mathrm{min})$ were added to the residue. Diethyl ether $(2 \mathrm{ml})$ was evaporated in the standard curve tubes $(0-300 \mathrm{pg}$, in triplicate) before addition of $\left[{ }^{3} \mathrm{H}\right]$ testosterone and antiserum. After incubation for $16 \mathrm{hr}$ at $4{ }^{\circ} \mathrm{C}, 1 \mathrm{ml}$ charcoal suspension was added. After $10 \mathrm{~min}$ equilibration and $10 \mathrm{~min}$ centrifugation, the supernatant was decanted into vials containing $10 \mathrm{ml}$ scintillation fluid.

The average $( \pm$ S.D. $)$ recovery of $\left[{ }^{3} \mathrm{H}\right]$ testosterone added to plasma samples as internal standard was $90.8 \pm 7 \cdot 3 \%(n=24)$. The water blank was $16.9 \pm 3.8 \mathrm{pg} / \mathrm{ml}(n=24$, range $4-28 \mathrm{pg})$. When known amounts of testosterone were added, recoveries after correction ranged from 94 to $107 \%$. The intra-assay coefficient of variation, assessed by measuring the same samples of plasma 10 times within a single assay, was less than $14 \%$. The results were corrected for the efficiency of extraction and the water blank value and expressed as $\mathrm{pg}$ testosterone/ml plasma.

\section{Chromatography}

Column chromatography was performed by the method of Carr, Mikhail \& Flickinger (1971) using $11 \times 0.8 \mathrm{~cm}$ columns of Sephadex LH-20 (Pharmacia, Sweden) in a hexane: benzene:methanol $(80: 10: 10$ by vol.) system. Plasma samples from different heifers at various stages of the oestrous cycle were subjected to column chromatography and the results are compared with those obtained without such separation in Table 1.

Table 1. Comparison of testosterone values in bovine plasma measured by radioimmunoassay before and after column chromatography

\begin{tabular}{|c|c|c|c|c|c|}
\hline \multirow[b]{2}{*}{ Sample } & \multicolumn{2}{|c|}{ Testosterone $(\mathrm{pg} / \mathrm{ml})$} & \multirow[b]{2}{*}{ Sample } & \multicolumn{2}{|c|}{ Testosterone $(\mathrm{pg} / \mathrm{ml})$} \\
\hline & $\begin{array}{l}\text { In ether } \\
\text { extract }\end{array}$ & $\begin{array}{c}\text { After } \\
\text { chromatography }\end{array}$ & & $\begin{array}{l}\text { In ether } \\
\text { extract }\end{array}$ & $\begin{array}{c}\text { After } \\
\text { chromatography }\end{array}$ \\
\hline 1 & 402 & 380 & 7 & 2520 & 2360 \\
\hline 2 & 422 & 436 & 8 & 2300 & 2370 \\
\hline 3 & 1149 & 1010 & 9 & 752 & 764 \\
\hline 4 & 3600 & 3480 & 10 & 54 & 52 \\
\hline 5 & 3700 & 3560 & 11 & 73 & 73 \\
\hline 6 & 1440 & 1500 & 12 & 74 & 69 \\
\hline
\end{tabular}

Since the testosterone antiserum cross-reacted in our laboratory considerably ( $44 \%$ ) only with $5 \alpha$-androstan-17 $\beta$-ol-3-one (DHT), thin-layer chromatography was performed on the same plasma samples as used for column chromatography. The thin-layer plates were freshly coated with Aluminoxide (Merck) $(0.25 \mathrm{~mm}$ thick) and washed in ethyl acetate. The plates were developed in the solvent system, chloroform : acetone (80:20 v/v), in which DHT ran ahead of testosterone (Cooper \& Waites, 
1974). Testosterone standards were visualized under u.v. light and DHT standards were seen after spraying with $35 \% \mathrm{v} / \mathrm{v}$ aqueous solution of $o$-phosphoric acid. After such procedures the plasma extracts showed no evidence of DHT but testosterone was present in every sample.

\section{Assay of other steroids}

Androstenedione concentrations were measured by radioimmunoassay after column chromatography as described elsewhere (Kanchev \& Dobson, 1976). Oestradiol and cortisol were estimated, without chromatography, by the methods of Dobson \& Dean (1974) and H. Dobson \&L.N. Kanchev (unpublished), respectively. The characteristics and limitations of the oestradiol assay were as described by Dobson \& Dean (1974); the cross-reaction with testosterone was $<0.01 \%$.

Progesterone in $1 \mathrm{ml}$ hexane extracts of $0 \cdot 1-0.5 \mathrm{ml}$ plasma was estimated by radioimmunoassay using a rabbit antiserum (RD/4.10) at a dilution of $1: 10,000$. The antiserum was prepared in this laboratory against progesterone-11-succinyl-BSA as described by Lindner, Perel, Friedlander \& Zeitlin (1972). The average recovery of $\left[{ }^{3} \mathrm{H}\right]$ progesterone added to plasma samples was $73 \cdot 1 \pm 6 \cdot 6 \%$ $(n=34)$. The water blank value was $8 \cdot 1 \pm 6 \cdot 0 \mathrm{pg}$, ranging from 0 to $20 \mathrm{pg}$. When $50,100,200,300$ and $500 \mathrm{pg}$ progesterone were added to plasma, the average recovery was $94 \%(n=12$ at each concentration) with an average interassay coefficient of variation of $17 \%$.

\section{Results}

\section{Steroid concentrations during the cycle}

The concentrations of testosterone, oestradiol and progesterone during the oestrous cycles of the 6 heifers are presented in Table 2. As the length of the cycle varied in each heifer, the results were standardized by considering Day 0 as the day of oestrus; Days -9 to 0 as days preceding oestrus, and Days 0 to +11 as days following.

Table 2. Mean ( \pm S.E.M.) plasma steroid concentrations during the bovine oestrous cycle

\begin{tabular}{|c|c|c|c|}
\hline Day of cycle & $\begin{array}{c}\text { Oestradiol } \\
(\mathrm{pg} / \mathrm{ml})\end{array}$ & $\begin{array}{l}\text { Progesterone } \\
(\mathrm{ng} / \mathrm{ml})\end{array}$ & $\begin{array}{c}\text { Testosterone } \\
(\mathrm{pg} / \mathrm{ml})\end{array}$ \\
\hline-9 & $7 \cdot 3 \pm 0.5$ & $3 \cdot 2 \pm 0.1$ & $78 \pm 15$ \\
\hline-8 & $5.3 \pm 0.6$ & $4 \cdot 1 \pm 0 \cdot 1$ & $88 \pm 18$ \\
\hline-7 & $10.4 \pm 3.9$ & $4.3 \pm 0.4$ & $1809 \pm 603$ \\
\hline-6 & $5.8 \pm 1.0$ & $4.3 \pm 0.5$ & $74 \pm 8$ \\
\hline-5 & $5 \cdot 6 \pm 1.1$ & $3 \cdot 9 \pm 0.3$ & $62 \pm 12$ \\
\hline-4 & $6.0 \pm 0.8$ & $4.0 \pm 0.5$ & $63 \pm 11$ \\
\hline-3 & $6.8 \div 0.4$ & $2 \cdot 1 \pm 0 \cdot 2$ & $68 \pm 13$ \\
\hline-2 & $7 \cdot 0 \pm 1.0$ & $1.0 \pm 0.1$ & $64 \pm 12$ \\
\hline-1 & $8.9 \pm 1.5$ & $0.3 \pm 0.1$ & $78 \pm 7$ \\
\hline $\mathbf{0}$ & $13 \cdot 5 \pm 1 \cdot 4$ & $0.1 \pm 0.1$ & $40 \pm 3$ \\
\hline 1 & $8 \cdot 7 \pm 1 \cdot 5$ & $0.2 \pm 0.1$ & $45 \pm 5$ \\
\hline 2 & $8.2 \pm 0.8$ & $0.5 \pm 0.1$ & $59 \pm 4$ \\
\hline 3 & $7 \cdot 5 \pm 1 \cdot 2$ & $0.7 \pm 0.1$ & $53 \pm 8$ \\
\hline 4 & $7 \cdot 0 \pm 1 \cdot 0$ & $0.9 \pm 0.1$ & $42 \pm 8$ \\
\hline 5 & $6 \cdot 7 \pm 1 \cdot 3$ & $1 \cdot 5 \pm 0 \cdot 1$ & $53 \pm 6$ \\
\hline 6 & $5 \cdot 8 \pm 1.2$ & $1.7 \pm 0.2$ & $53 \pm 9$ \\
\hline 7 & $5 \cdot 6 \pm 1 \cdot 1$ & $2.0 \pm 0.2$ & $52 \pm 8$ \\
\hline 8 & $5.6 \pm 1.2$ & $2.5 \pm 0.4$ & $50 \pm 7$ \\
\hline 9 & $5 \cdot 8 \pm 1 \cdot 0$ & $2 \cdot 8 \pm 0.5$ & $55 \pm 10$ \\
\hline 10 & $6 \cdot 3 \pm 1 \cdot 2$ & $2.7 \pm 0.4$ & $60 \pm 6$ \\
\hline 11 & $6.4 \pm 1.5$ & $2.8 \pm 0.5$ & $62 \pm 9$ \\
\hline
\end{tabular}


The lowest concentration of testosterone was measured on the day of oestrus. A minor rise was detected on Day +2 , after which the concentration of testosterone remained low. A sustained increase in plasma testosterone was observed after Day +11 with a peak on Day -7 . The 6 heifers were each bled for 30 days and a total of 9 oestrous periods were detected: similarly, 9 peaks of testosterone concentration were observed ranging from 402 to $3700 \mathrm{pg} / \mathrm{ml}$ on Days $-5,-6,-7$ or -8 . On the day preceding oestrus, another much smaller peak was measured.

The concentrations of progesterone and oestradiol represent the usual pattern of secretion during the cycle. The lowest concentration of progesterone was measured around oestrus and the highest on Days -7 and -6 . Oestradiol began to increase 2 days before the peak at oestrus and another increase occurred on Day -7 concurrent with the maximum testosterone concentration.

\section{Effect of betamethasone treatment}

The oestrous cycles of the 5 heifers treated with betamethasone were prolonged by about 10 days; after treatment beginning on Day 10 of the cycle, oestrus occurred on average 21 days later (range 15-28 days). The plasma progesterone concentrations remained at luteal values $(3-6 \mathrm{ng} / \mathrm{ml})$ throughout betamethasone treatment until just before oestrus, indicating that the corpora lutea palpated per rectum were functional.

Profound adrenal suppression was indicated by depressed cortisol concentrations throughout the sampling period, even after cessation of betamethasone treatment. The concentration of oestradiol increased significantly above baseline (from 8 to $17 \mathrm{pg} / \mathrm{ml}$ ) in only 2 animals for 3 days before oestrus. Androstenedione values before and after betamethasone treatment did not differ from those during treatment. The testosterone concentration was $13.0 \pm 2.4 \%$ (mean \pm S.E.M.) lower during than before and after betamethasone treatment $(P<0 \cdot 01$, paired Student's $t$ test: Snedecor, 1946). Only in one animal did very high peaks of testosterone $(>4 \mathrm{ng} / \mathrm{ml}$ : baseline $80-100 \mathrm{pg} / \mathrm{ml})$ occur as described in the normal cycle. One peak occurred 1 day after the beginning of betamethasone treatment and another was observed 4 days after the last injection. This heifer did not come into oestrus for another 15 days. In none of the other 4 heifers did testosterone peaks above $80 \mathrm{pg} / \mathrm{ml}$ occur.

\section{Discussion}

The results show that testosterone is present in bovine peripheral blood during the oestrous cycle in much higher concentration than oestradiol, possibly reflecting greater ability of the ovary to produce testosterone. Shemesh \& Hansel (1975) found that, after $2 \mathrm{hr}$ incubation of follicles isolated from Holstein heifers, the concentration of testosterone in the medium was higher than that of oestradiol and that this difference was accentuated after incubation with bovine LH or PGF-2 $\alpha$ while very little change was observed in progesterone synthesis.

The concentration of testosterone reported here is higher than that reported by Shemesh \& Hansel (1974). There is, however, close similarity in the pattern of secretion previously described, with the exception of the peak occurring around Day -7 , which was not observed by Shemesh \& Hansel (1974). To prove that the peak consisted only of testosterone, all samples from this day were subjected to column and thin-layer chromatography. The results were very close to those obtained without separation. The peak was detected in different heifers from Day -5 to Day -8 but in each case the peak preceded the day on which progesterone concentration began to decrease. The physiological importance of the peak is not clear. Testosterone-may be only a precursor in the synthetic pathway of oestrogens or may act as synergist in the induction and manifestation of oestrus.

The suppression of adrenal function, followed by a delay in the appearance of oestrus, has been reported only once previously: Liptrap (1970) observed a 1-3-day prolongation of cycle length in pigs with subsequent shortened duration of oestrus. The delay reported in the present study was, however, much longer. Plasma androstenedione concentrations did not decrease significantly during adrenal suppression, suggesting that the adrenal cortex is not normally the source of this hormone in bovine peripheral plasma, as has been reported for women (Baird, Burger, Heavon-Jones \& Scara- 
muzzi, 1974) and sheep (R. J. Scaramuzzi, personal communication). The lowered values for testosterone suggest a partial adrenal contribution to peripheral plasma values and the simultaneous absence of testosterone peaks with suppression of adrenal function is interesting. There is no evidence in the present study of an action of betamethasone on ovarian enzymes, but the possibility that increased testosterone secretion is a necessary precursor for normal luteal regression warrants further investigation.

We thank the International Atomic Energy Agency, Vienna, for a Fellowship to L.N.K.; the Animal Health Trust for a Wooldridge Fellowship to H.D.; the Agricultural Research Council for further financial assistance; and Mrs Sandie Midmer for excellent technical assistance.

\section{References}

Abraham, G.E. (1974) Ovarian and adrenal contribution to peripheral androgens during the menstrual cycle. J. clin. Endocr. Metab. 39, 340-347.

Baird, D.T., Burger, P.E., Heavon-Jones, G.D. \& ScaramuzzI, R.J. (1974) The site of secretion of androstenedione in non-pregnant women. $J$. Endocr. 63, 201-212.

Carr, B.R., Mikhail, G. \& Flickinger, G.L. (1971) Column chromatography of steroids on Sephadex LH20. J. clin. Endocr. Metab. 33, 358-360.

COOPER, T.G. \& WAITES, G.M.H. (1974) Testosterone in the rete testis fluid and blood of rams and rats. $J$. Endocr. 62, 619-629.

Dobson, H. \& DeAN, P.D.G. (1974) Radioimmunoassay of oestrone, oestradiol-17 $\alpha$ and $-17 \beta$ in bovine plasma during the oestrous cycle and last stages of pregnancy. $J$. Endocr. 61, 479-486.

Donaldoson, L.E., BassetT, J.M. \& Thorburn, G.D. (1970). Peripheral plasma progesterone concentration of cows during puberty, oestrous cycles, pregnancy and lactation and effects of undernutrition or exogenous oxytocin on progesterone concentration. J. Endocr. 48, 599-614.

Glencross, R.G., Munro, I.B., Senior, B.E. \& Pope, G.S. (1973) Concentration of 17 $\beta$-oestradiol, oestrone and progesterone in jugular venous plasma of cows during the oestrous cycle and in early pregnancy, Acta endocr., Copenh. 73, 374. 384.

JUDD, H.L. \& YEN, S.S. (1973) Serum androstenedione and testosterone levels during the menstrual cycle. J. clin. Endocr. Metab. 36, 475-481.

KANChEV, L.N. \& Dobson, H. (1976) Plasma concen- tration of androstenedione during the bovine oestrous cycle. J. Endocr. (in press).

Lindner, H.R., Perel, E., Friedlander, S. \& Zeitlin, A. (1972) Specificity of antibodies to ovarian hormones in relation to the site of attachment of the steroid hapten to the peptide carrier. Steroids 19, 357-375.

LIPTRAP, R.M. (1970) Effect of corticotrophin and corticosteroids on oestrus, ovulation and oestrogen secretion in the sow. $J$. Endocr. 47, 197-205.

MCCRACKEN, J.A., BAIRD, D.T. \& GODING, J.R. (1971) Factors affecting the secretion of steroids from the transplanted ovary in the sheep. Recent Prog. Horm. Res. 27, 537-582.

Rowe, P.H., Lincoln, G.A., Racey, P.A., Lehane, T., Stephenson, M.J., Shenton, R.C. \& Glover, T.D. (1974) Temporal variations of testosterone levels in the peripheral blood plasma of men. $J$. Endocr. 61, 63-73.

Shemesh, M. \& HANSEL, W. (1974) Measurement of bovine plasma testosterone by radioimmunoassay (RIA) and by a rapid competitive protein binding (CPB) assay. J. Anim. Sci. 39, 720-724.

Shemesh, M. \& Hansel, W. (1975) Stimulation of follicular steroidogenesis by $\mathrm{PGF}_{2 x}$ and LH. J. Anim. Sci. 41, 379, Abstr.

SHORT, R.V. (1962) Steroids present in the follicular fluid of the cow. J. Endocr. 23, 401-411.

SNedecor, G.W. (1946) Statistical Methods, p. 44. Iowa State College Press.

Tribble, R.L., Sorenson, A.M., Woodward, T.L., CONNOR, J.S., Beverly, J.R. \& FleEger, J.L. (1973) Serum progestins and LH levels in non-suckled primiparous heifers. Nature, Lond. 246, 494.

Received 26 May 1976 